\title{
Houses of the Polish-Belarusian borderland as areas of value
}

\author{
Magdalena Sulima \\ Faculty of Architecture; Bialystok University of Technology; Oskara Sosnowskiego Street 11, \\ 15-893 Bialystok, Poland \\ mssulima@poczta.onet.pl; ORCID: 0000-0002-0807-9417
}

\begin{abstract}
Nowadays, as a result of globalization processes, the sense of identity and relationship between humans and their place of living is increasingly losing its importance. Today's thinking about the house as a centre of the world is becoming less obvious in comparison to the symbolism of a house in the folk culture. Wooden houses on the Polish and Belarus border are an example of a temporal continuum - both in the spatial and in the spiritual aspect. Because of their architecture, decoration on facades and spatial layout, they are a distinctive feature of the local landscape, and ethnic communities inhabiting them, to this day have maintained a strong identification with their own roots and place of residence. The greatest threat to the continuity of local tradition as well as wooden architecture of borderland villages is their progressive extinction. That is why the issue of protection of the cultural heritage and the generational memory of local residents is one of the key issues in maintaining the identity of those areas. The aim of the article which is based on ethnographic sources and field researches is to present the symbolism of traditional wooden houses in the villages of the north-eastern Poland as areas of material and spiritual values and to bring attention to the need of protecting them in the context of contemporary civilization changes.
\end{abstract}

Keywords: borderland, wooden houses, protection, cultural heritage, intergenerational transmission

\section{Introduction}

At the turn of the twenty-first century, inevitable globalization processes in the contemporary world have shown how fragile and unstable terms such as tradition, religion, and identity have become. These terms, once very important to one's idea of self, have gone into oblivion, losing their rank. Such changes in civilization have also had influence on something particularly important to human beings: their place of residence.

In folk culture, the relationship between man and home was based on strong foundations such as the father's faith and intergenerational relationships, causing people to strongly identify with the space they occupied. Nowadays, thinking about home as the most important place on earth, as a refuge from the fast-paced world and a community for the people living in it (families), is less obvious when compared to the symbolism attached to traditional ways of living. Our lives, in contrast to past periods, seem to be detached from the cycle of generations as a way of measuring time [1, p.200]. The transformation and deepening crisis in terms of adherence to traditional values has become a subject of twentieth century philosophical thought ${ }^{1}$. Anthony Giddens stated that the modern world is a very different place compared to the world our ancestors lived in. For

1 Martin Heidegger, Gerardus van der Leeuw, Emmanuel Levinas, Gaston Bachelard, Mircea Eliade and Józef Tischner, among others, wrote about the recession of traditional values. 
them, religion and customs passed down from generation to generation were integral determinants of norms regulating social behavior, and order in the world was determined by thinking about the world through the prism of faith. The doctrine of modernity has achieved success by breaking down traditional ideas about lifestyle, community, and a lack of authority [1, p.8-9].

Advancements in civilization, economic progress, and the spread of mass culture have left their mark not only in the socio-cultural sphere and the nature of life in urban agglomerations, but also on the cultural life of the countryside. These changes are noticeable both in the cultural landscape of rural areas (where new and modern forms are being introduced) and in the field of spiritual culture (where the human bond with the place of his birth - one of the most important and the most lasting existential values - is slowly passing away and is moving into non-existence). Analysis of the phenomenon of the home, and its role in social culture, is an activity that is very important and relevant nowadays, since the home contains both material (building) and psychological (emotional) components.

An example of the existence of a temporary continuum - both in architectural and spiritual aspects, are the wooden houses of the Polish-Belarusian borderland close to Białowieża Forest ${ }^{2}$. These homes, with their form (building material, construction, façade decoration) and placement in the rural setting, constitute a distinctive feature of the local landscape. The ethnic communities that inhabit this region are made up of people with affiliations in terms of nationality (most declare themselves as Belarusians) [4, p.114], religion (most are members of the Orthodox Church), linguistics (speaking a combination of Polish, Belarusian and Ukrainian languages) and space.

The eastern borderland of Poland are areas where Polish culture meets eastern cultures, i.e. Belarusian, Lithuanian, Ukrainian and Russian [5, p.9]. This refers to the penetration of both national as well as civilizational elements - this is the borderland between the Latinand Byzantine cultures [6, p.298]. Interestingly, in these sites the sense of religious affiliation is also often a criterion for determining national belonging. That is why the communities describe themselves as "local", "Orthodox", "Russian" or "Belarusian" [7, p.80, citing: 41]. This "socio-cultural phenomenon" [8, p.23] of the dependence of Orthodoxy and Belarusian heritage, historically and currently exert a colossal impact on the entire life of the inhabitants [9, p.508]. These ethnic groups, in opposition to modern society strongly connected with urban culture, to this day have a strong connection with local tradition, their roots and place of residence. This is visible in the preserved architecture of houses and in activities connected not only with day to day living, but also to holidays. This shows how multifaceted the issue of wooden architecture is.

The aim of this paper, based on ethnographic sources and field studies, is to present the symbolism attached to traditional wooden architecture found in the villages of the north-eastern part of Poland (Bielsk Podlaski, Czyże, Hajnówka and Narew communes), as areas of both material and spiritual value and bring attention to the need of protecting them in the context of contemporary civilization changes.

2 According to sociologist Andrzej Sadowski, the term "borderland" defines the area, zone, territory on which two or more ethnic and cultural groups come into contact [2, p.17], the consequence of which is the inevitable penetration and assimilation of certain elements of the culture (including language, religion, customs). In terms of geography in Poland, three borderlands can be distinguished: southern, eastern and western. Sadowski included: Podlaskie, Warmian-Masurian, Eastern Mazovian, Lubelskie and Podkarpackie Voivodships [3, p.27] in the eastern borderland areas. The phenomenon of the eastern borderland in the socio-cultural aspect is a frequent subject of analysis by many researchers, including Włodzimierz Pawluczuk, Grzegorz Babiński, and Marek Barwiński. 


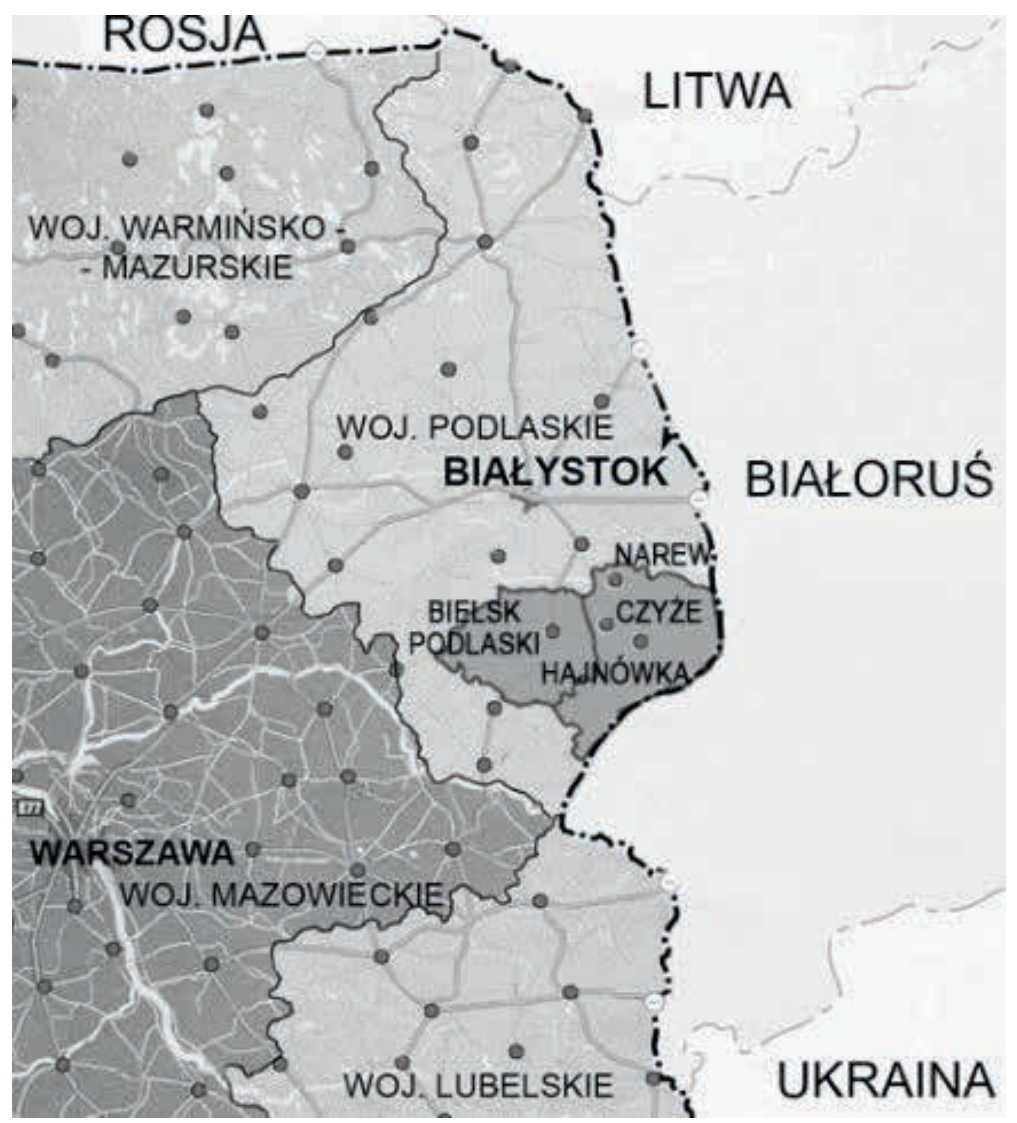

Fig. 1. Location of the research area (Bielsk Podlaski, Hajnówka, Czyże, Narew communes) within the borders of the Podlaskie Voivodeship; source: author based on the map of Poland according to the administrative division

\section{The cultural landscape of the borderland village}

The villages of eastern borderland Poland, located on the border with Belarus, are characterized by a settlement system created in the 16th-century. It is the result of a great agrarian reform carried out by Queen Bona Sforza in the years $1558-1561^{3}$. The layout and proportions of the plots are very similar in that they are very elongated. They begin with the residential house set sideways with its peak to the main road (after WWI, when they were built with the roof ridge parallel to the road), the road being the axis around which the whole village was built. The outbuildings were built in a row behind the residential house. The arable fields were located even further from the main road, across a smaller road which ran behind the barns. After later transformations in agriculture, arable fields were also located much further away from inhabited areas (phot. 1).

3 During the reform almost all lands belonging to Queen Bona were measured. The scale and enormous size of the enterprise is demonstrated by the number of measured lands in Podlasie, Lithuania and Belarus. According to Marian and Wojciech Pokropek, by the 1566-67 there were about 1231 hectares measured [10, s.104]. 


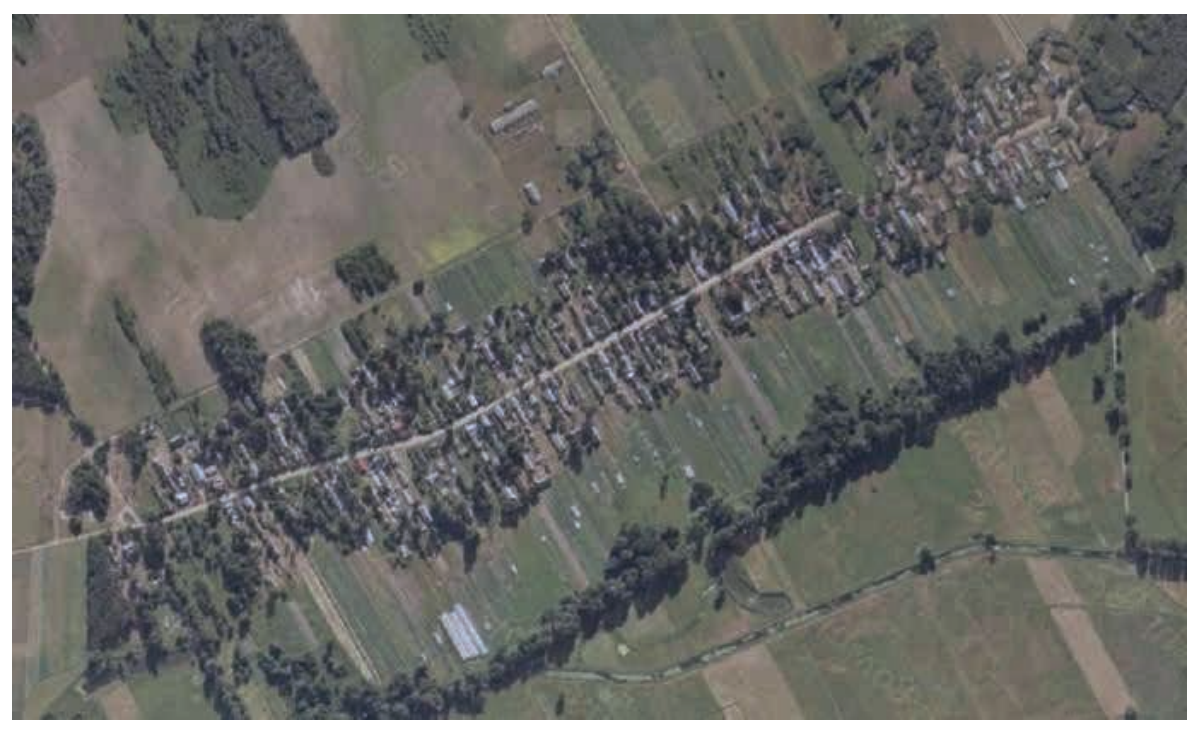

Photo 1. Satellite map of a fragment of Deniski village (Bielsk Podlaski commune), scale 1: 12000; source: google maps

The distinctive features of the local rural landscape are undoubtedly the original wooden houses and their specific characteristics. They were built over a period of hundreds of years through natural development of the region, and in accordance with traditional patterns. A flower garden, which first appeared in the 1920's - 1930's, usually occupies the front lawn, where a cross has been placed to show gratitude, and a bench to permit for social gathering among older residents of the village (phot.2-4).
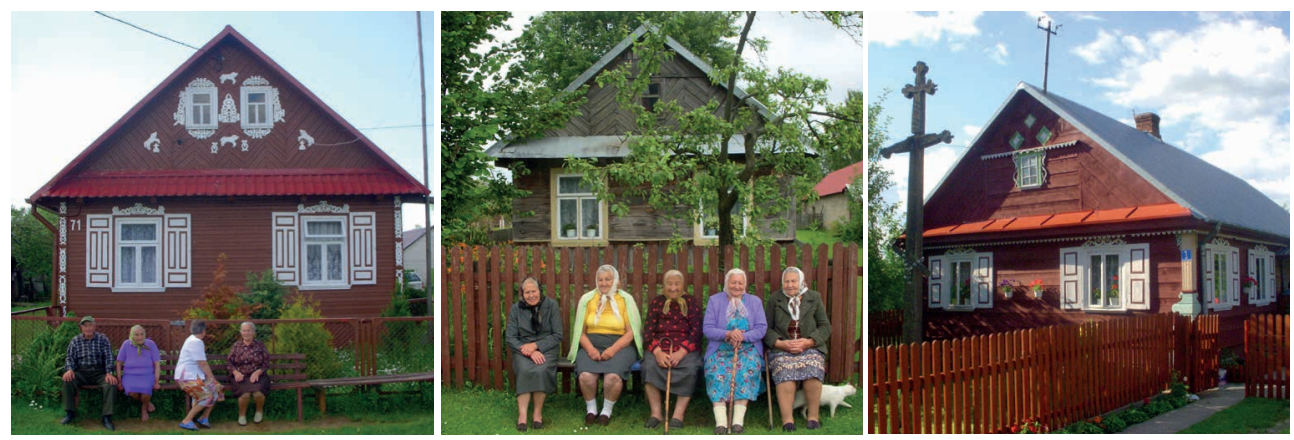

Photo 2-4. Phot.2. Plutycze village (Bielsk Podlaski commune), Photo 3. Stare Berezowo village (Hajnówka commune), Photo 4. Kojły village (Czyże commune), All photos by the author

Until the end of the 19th century, the cottage consisted of one room that was heated with a massive "Russian" clay stove located in the corner of the room, next to the door. Its corner-wall location was also found in Belarus, Ukraine and Russia [11, p.37, citing: 42, p.147]. Cottages were either detached houses or were connected with livestock buildings and covered with a common thatched roof. Over the years (starting in the interwar period), houses were built in two-way 
systems with gabled roofs. During the same time period, the facades of the houses began to be decorated with ornaments cut out of wood. Windows, shutters, corners, peaks, porches and verandas were decorated with plant and animal motifs (phot. 5-7). The colorful walls of the buildings, with their bright ornaments, create a folk, fairy-tale, magical climate that is unique on a national and international scale ${ }^{4}$. The decorations should not, however, be treated only as products of folk art created by local craftsmen. The symbolism attached to this form of architecture runs much deeper, combining religious themes with the community's common imagination about the world going back to pagan times [12, p.13]. The external source of inspiration was primarily the surrounding nature. Motifs appearing on the houses in the form of twigs, birds, hearts, suns - derive from the world of fauna and flora, as well as religious-cosmic compositions. For example, the motif of pigeons symbolised love, clover - life, and sun - happiness. Therefore, each decorative element had a different, sometimes not entirely rational meaning, emphasizing the strong relationship of its place on earth with transcendent forces [13, p.107].

Residents are mostly Orthodox and this religion, apart from the theological aspects, represents a particular lifestyle which is also reflected in the cultural and moral layer [14, p.41], [13, p.95-108]. The essence of this religion is the cult of spirituality and mysticism. Orthodoxy, as Eastern Christianity compared to Western Christianity, is more mystical and "out of this world" [15, p.168]. It is based on symbols and characterized by sensual and intuitive knowledge of God. The Eastern Church has always been open to the phenomenon of folk religions, therefore religion in the villages is very often a cluster of specifically understood dogmas of the church, traditions passed down from generation to generation and folk traditions that bordered on what could be called magic [13, p.111], [16, p.577]. The strong dependency between the religious and the cultural system allows for the use of the concept "religious society" in relation to the people living there [17, p.12. citing: 43]. Religion was, and remains, one of the most important and enduring aspects of life for inhabitants, and provides the canon for creating, arranging, and decorating a home and its surroundings, as well as defines and regulates acceptable behavior and habits in terms of the use of its space.
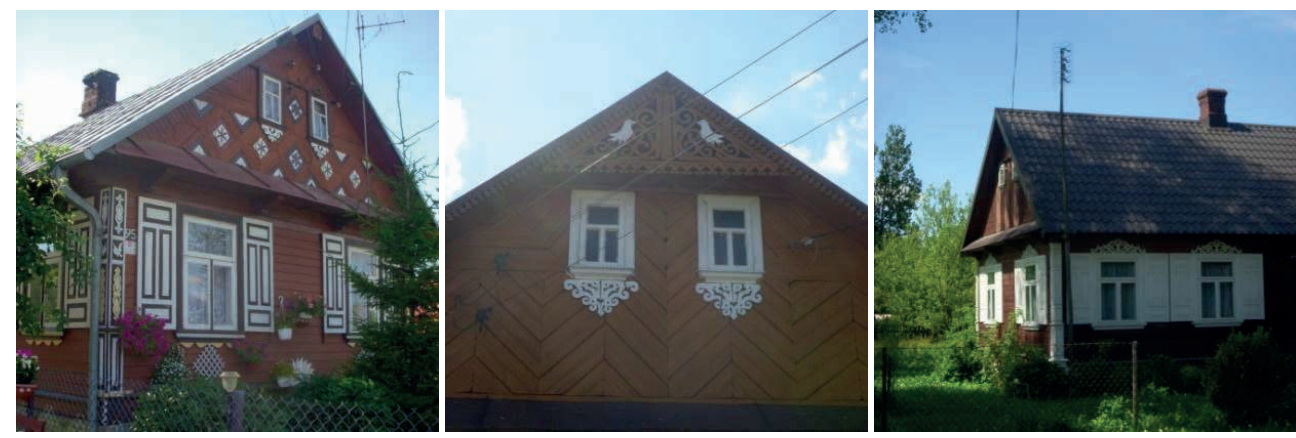

Photos 5-7. Phot.5-6. Czyże village (Czyże commune), Photo 7. Nowoberezowo village (Hajnówka commune), All photos by the author

4 To this day, the ornamental elements on the houses are made by local carpenters living in these areas. In the village of Ciełuszki (Zabłudów commune) it is done by Jan Szarkiel, in Kaniuki (Zabłudów commune) Włodzimierz Naumiuk is the local carpenter and sculptor, and in the village of Plutycze (Bielsk Podlaski commune) until recently it was done by Michał Grygoruk and Jan Onopiuk. However, this is the last generation involved with this profession. 


\section{The home in traditional borderland culture}

Historically, in the culture of the countryside, the word "home" had a basic and constitutive meaning. The traditional vision of the world had not so much a historical, but rather a cosmological character [18, p.17]. In folk consciousness, the house of man on earth was to be a reflection of the house of God, and its construction was to be identical with the creation of the world, as a reconstruction of the time of creation [19, p.46]. This conviction was already evident during the preparation and laying of the foundation of the house, which had to be carried out according to strictly defined rules, dictated by tradition. Various rituals at different stages of the build were important here: such as choosing a plot that had been indicated by sacred powers, marking it with a cross, the making of offerings to bring happiness and prosperity to the inhabitants of the space, cutting down the right trees, and the customary behavior of the craftsmen. The decision about the area on which the future cottage was to be erected was governed by many rules, and the area had to be uncontaminated and ritually cleaned [19, p.16], [20, p.443]. Only then could the foundations, walls, doors, windows be installed and covered with a roof. At the end of construction, the house was decorated with colorful ribbons, paper and a sprig of spruce placed on the last rafter (so called "wianek"), and the completion of the construction (in the local dialect was called "winkowe") was celebrated with dance and music. The house was compared to a tree: in the basement it had its roots, and the roof was crowned with a crown [21, p.308], and through its opening (chimney) was a link with the world of sacrum. From the first moments of existence there was a strong bond between man, home and God. This is also reflected in the activities carried out during the next stages of the build, such as sprinkling the foundations with holy water, referring this to the gesture of God creating the world, or walking around the building with a holy image as a sign of taming and taking possession of the space. The home, built on such a solid foundation, could accompany a person throughout their life, and constitute a framework for the subsequent stages of their existence. The home was therefore a birthplace: the view from the windows was a person's first view of the world; they matured here, and eventually passed away in this space [22, p.43]. By saying: "I am from here", "I am from this house", "this is my land" - people identified with their surroundings. This attachment to one's space had primarily a spiritual and psychological value, but also an intimate one.

The home was treated by village residents as a space of value in which a person grew up, took root and was bound to for years. This symbolic relationship was revealed most during the celebration of annual holidays and in important moments in a person's life, such as birth, weddings or funerals, in which the ritual activities performed within this space were symbolically "created and recreated again" [23, p.58]. It is worth mentioning the custom of laying a newborn child on the stove, which is meant to strengthen the relationship between the person and their home, or knocking of the coffin on the doorstep of the house, as a sign of the last goodbye of the deceased with the house in which he was born, worked and died. Therefore, the house was connected to man from the beginning, until the end of his life.

The bond between the home and the fatherland was not broken within the culture of the countryside. This bond, as a heritage of fathers, had both earthly and spiritual connotations [24, p.9]. The area acquires the meaning of the fatherland when a given community refers to it in a certain way, thus shaping its image [ 25 p.18]. On the Polish-Belarusian borderland, the concept of home is not autonomous in relation to mental and emotional attitudes. Here, the family home has been compared to a private and intimate homeland, the most important place on earth. A home that was metaphorically called a family nest or the land of childhood, was inevitably associated with the motif of cradle and childhood, a synonym of shelter, safety and joy [26, p.223], [18, p.22]. The image of the parents constitutes the multitude of references showing the home environment as a happy place [26, p.224]. The mother - a woman who has given birth to a child, a caregiver. The 
father (patrimony) - a symbol of stability and refuge. Stanisław Ossowski wrote that "the family land is the land where you come into the world. At the same time, the family land is etymologically associated with the concept of family and ancestry" [27, p.44]. The cult of ancestors who lived and died there was therefore the most durable link that unites the family land and the home. "Through the parents, the fatherland is the land of fathers, the land to which fathers were bound by birth and a long chain of experiences; through blood they gave this relationship to their children" [27, p.27]. The villagers' awareness of past generations and the emotional attachment towards their place on earth have become distinctive features of their moral attitudes.

The home, in the whole system of folklore, was undoubtedly made up of the community of people living in it. As a hierarchical institution, the home connected generations: grandparents, parents and children [22, p.46, citing: 44]. Such a traditional home also had its own psychic temporal extension: here lived the past, present and future. The home gave its inhabitants an opportunity to look back at events and situations in the past and, at the same time, it was also a place to dream about the future [26, p.224-225]. The very sense of belonging to the family community and intergenerational memory - merged and grounded the home. This is confirmed by Jerzy Bartmiński, who wrote that, according to popular belief, the aspect of communality dominates over location [28, p.36].

Even today, in many houses of the eastern borderland one can encounter traces and memorabilia of the past, which are a confirmation and a preserved piece of the history of people living there and a tangible record of fragments from their lives. These items constitute the foundation of the identity of a given family built over the years by the history of the ancestors. Memories belonging to the home, however, are not only tangible objects, but also non-material - such as sounds, songs, and smells (pastries prepared by housewives), annual holidays designated by the Julian calendar, as well as family celebrations (baptisms, weddings or funerals) formerly took place in the home and were accompanied with music and song, with the whole household engaged, utilizing specific items found in the home. Even today, in many Orthodox homes, the corners of the interior are decorated with sacred images - patron icons decorated with small aprons, small curtains or towels, which, according to their belief, protect the living space and its household from danger. The floors are decorated with hand-sewn carpets. There are huge embroidered cushions displayed on the beds in guest rooms (photos 8-9). These cushions were passed down from generation to generation as a dowry of the bride. Thanks to these memorabilia and memories that have been cultivated over time, these spaces acquire symbolic importance and become rich in meaning.
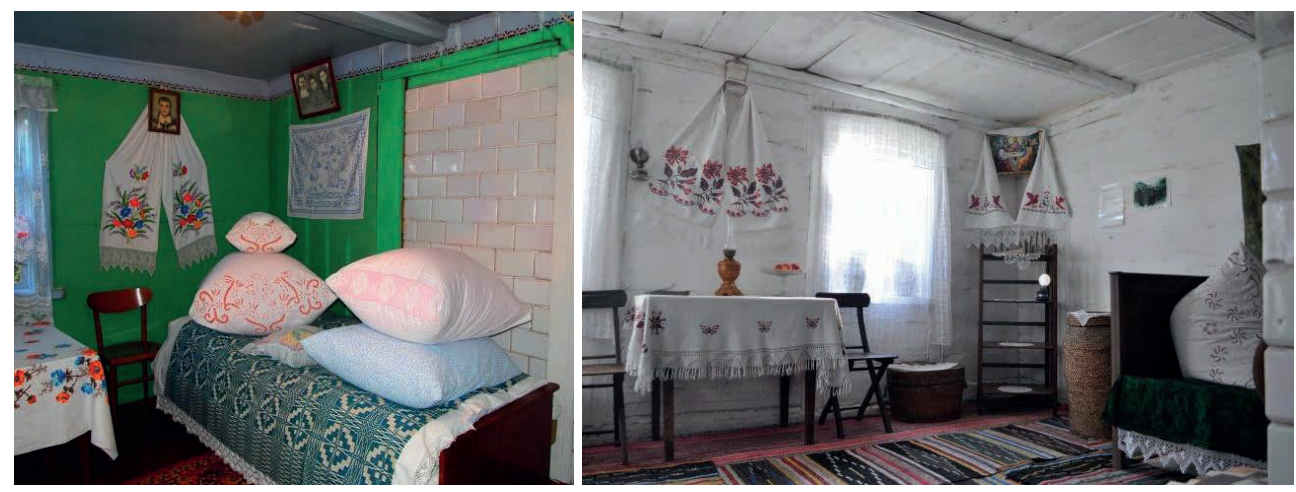

Photos 8-9. Soce village (Narew commune), photos by M. Dekutowska, P. Jungiewicz (students of the Faculty of Architecture at Bialystok University of Technology) 
In the analysis of borderland homes, apart from their architectural (visual) value, it is not possible to omit the "humanistic coefficient" [29, p.36, citing: 45, p.50]. "The home as an interiorised space, as Hanna Buczyńska-Garewicz wrote, can be experienced and felt and, undoubtedly, it is a common and fundamental experience (...) it unifies many different types of egos. Conscious and subconscious, intellectual, emotional and volitional experiences intertwine with one another, different needs of the soul come to the fore. Memory is connected with a dream" [26, p.220, 224]. In the rural tradition, the home was undoubtedly a space of cultural significance, a space for passing down traditions and material artifacts through generations. Behaviors learned from the family home, ethical and moral values, attitudes toward one's surroundings, prayers, songs, repeated gestures, are all evidence of how strong the connection is between inhabitants and their place of residence.

\section{Present day}

The cultural landscape of the eastern villages of Podlasie is a very broad topic. Being a spatial record of the history of previous generations and a reflection of the relationship between people and their living space, it contains many themes and references that penetrate the dependencies between the material and the spiritual. On the one hand, the preserved spatial arrangement of the plot, the wooden architecture, the façade decoration, as well as the interior decoration, evoke the past of the ethnic communities who have lived here. On the other hand, it shows a "cultural and visual reality", and "a unique image of their lives" [30, p.45], presenting the local culture and how they experience their space.

Interestingly, the houses of the eastern Polish borderland to this day shape the character of these lands, constituting their identity. The houses are a tangible and indirect link with history. In addition to the typical utility function - as a space for living, they also have a symbolic dimension - they contain a compilation of meanings, spiritual and sensual: the memory of generations with a deep layered belief system and strong cultural and social relations. And although there are signs of passing time on them, they are still a living example of the bond that exists between that what was and the present, and shows the emotional dependency between man and home, which is quickly disappearing in the modern world.

Despite the now-widespread crisis of ideology, the model that grew on the foundation of the fathers' faith, respect for the past, for the legacy of generations, and for customs, has become a permanent part of the lives and memories of local residents. As opposed to the modern world, the main and integral distinctive feature of norms regulating social behavior in this region is religion, present in almost every home. Residents cultivate traditions, following a certain code of duty toward their small private homeland. Home, as a space for living in the folk tradition, has ideological value, and symbolism still influences the organization, preservation and experiencing of the space [13, p.247, 250].

Citing the words of Sebastian Bernat, it can be concluded that in the analysis of the phenomenon of the home, it is difficult to separate the intangible aspects "from their material roots, intangible values of the landscape (including historical values, originality, uniqueness, symbolism) strongly affect the intellectual and emotional sphere" [31, p.129]. The inseparable connection between the two is also contained in the Unesco Convention of 2003, which states that: “(...) there is a far-reaching interdependence between material cultural heritage and intangible cultural heritage [32], and: If material culture upholds the identity of the nation, then certainly spiritual, intangible heritage creates, shapes, enriches and stimulates material expression" [33]. 
The prospect of survival and continuity of the cultural memory of the homes and the customs and rituals connected to the home, as well as the survival of the wooden architecture itself in the villages of south-eastern Podlasie is becoming more and more precarious every year. This is mainly due to the demographic situation and the inevitably progressing phenomenon of the depopulation of rural areas in the eastern region. Field research shows that at the moment, the villages are inhabited by generations of people aged $60-90$, most of whom are retired and no longer employed in agriculture ${ }^{5}$. This state was caused, among others, by the economic and social situation that took place in Poland after 1990, and more specifically mass emigration to cities, change of life model, self-realization of the young generation outside agriculture, the expansion of mass media, and thus the spread of mass culture [34], [13, p.248]. This situation is confirmed by Sokrat Janowicz, who writes: "Belorussian life is characterized by a certain paradox: the city swallows the ethnic mass at a dizzying pace (...)" [35, p.241].

Most of the children and grandchildren have left to neighboring cities, visiting grandparents mainly for holidays or family celebrations. An aging population and the desertion of the villages by young people have caused certain elements of folk culture, both material and spiritual, to change. In the architectural context, this is manifested by a growing number of abandoned houses, with the number increasing every year. An important problem is the low durability of wood as a building material. It is quickly destroyed, and older residents do not have funds to modernize their homes. On the other hand, in the village landscape, new buildings are increasingly found among traditional buildings, whose form, roof shape and building material are far from local standards developed over the years. New owners - usually not family-related to those originally living here, mostly come for vacation and seek to modernize their summer houses. Wooden windows are replaced by plastic ones, and facades are covered with siding, and it is increasingly common that beams are stripped of their decorative details [9, p.509].

The growing phenomenon of depopulation of the villages of the Polish-Belarusian borderland also affects the spiritual layer of the community. Among the inhabitants, the frequency of traditional household practices is diminishing or disappearing altogether. Often, it also happens that behavioral patterns, passed down in families for generations, are colored with contemporary elements brought to the countryside by the younger generations. The situations described are an inevitable echo of civilization advancement that has not been indifferent to the rural areas of eastern Poland.

\section{Conclusions}

Nowadays, globalization and its trends have priority over the building of community and a relationship with one's place of residence. This is why the issue of spiritual and material protection of the borderland heritage is today a priority in order to maintain the identity of these areas, and to be remembered and respected by future generations. The enormous cultural capital that the villages of south-eastern Podlasie have at their disposal is its most important attribute, which should be preserved at all costs.

\footnotetext{
Field research was conducted individually and with a group of students as part of the inventory practice organized by the Faculty of Architecture at the Bialystok University of Technology from 2008-2019. Research included villages from Bielsk Podlaski, Czyże, Hajnówka, Narew communes and concerned rural wooden houses (architecture, construction, detail) and customs related to the residential space of local communities.
} 
The villages of eastern Poland are areas where many wooden buildings have survived. The current forms of protection of wooden houses concern only buildings which have the status of monument. The owners of such buildings receive funds to keep them in proper condition. The procedure for applying for such funding is not easy, which discourages interested persons from taking actions aimed at changing the legal status of a residential building. In the areas of the Polish-Belarusian borderland, many houses are not listed in the register of monuments, but have significant cultural value. Protecting them against liquidation consists of including them, where possible, in local plans, or in case of the inability of maintaining the building, informing potential buyers about the possibility of buying or leasing the house, including the possibility of relocating the house to another area. Although the issue of the protection of wooden buildings is included in the activities of cultural institutions and the conservationists, so far mainly legally unregulated actions have been taken. In fact, their condition depends on the will and decisions of private owners who, due to lack of financial resources, do not always care about keeping the house in proper condition. For the most part, these houses are from the 1930s and 1940s and are distinguished by rich architectural detail [34].

The protection of the intangible elements of the heritage of the communities living in these areas is also extremely important. However, this requires a comprehensive and multi-directional studies approach. Ongoing debates around the country about the protection of cultural heritage emphasize that such activities should primarily be carried out by various entities, including conservators, local governments, universities, schools, and focused on cognitive, educational, revitalization and touristic projects. They also articulate active and practical engagement and inclusion of rural communities. These activities can serve as a way to activate the community and pay tribute to the values they represent, as well as serve as a way to build intergenerational bonds.

The activities of municipalities that are closest to local communities have the most impact on the aspect of protection in situ. Besides the relevant provisions in cultural policy, which is part of the regional or local development strategy, this is done by promoting local cultural tourism, which in the future may contribute to the economic dynamism of these areas. Common concern for heritage is identification, documentation, research and promotion, as well as transmission and formal and informal education. That is why, as part of initiatives supporting the promotion of the heritage of ethnic groups in Eastern Podlasie, grassroots projects run by local communities are also appearing more and more often. They aim to disseminate their knowledge and skills related to tradition (oral, music, building practices, handicrafts and culinary traditions), while leading to increasing awareness of the need to maintain them. In the case of Eastern Podlasie, as Małgorzata Durydiwka and Piotr Kociszewski note, the multiculturalism of this area and the possibility to interact with locals who continue to practice traditions can find a "permanent place in the catalog of cultural heritage" or be recreated [36, p. 6].

The postulate for the intergenerational vector of information coincides with the provisions of the Unesco Convention on the Protection of the World Cultural and Natural Heritage of 1976, in which article 27 addresses the issue of strengthening the attachment to cultural and natural heritage [37], as well as the latest Unesco Convention of 2003 on the protection of intangible heritage [32], which talks about securing and respecting all manifestations (customs, rituals, ideas, values, skills and related objects and artifacts) inherited from ancestors, as well as raising public awareness on this topic.

The idea of protecting cultural heritage, both architectural and spiritual, puts an emphasis on the active role of local communities in transferring their knowledge and skills. "Culture, as 
Stanisław Ossowski wrote, is (...) a certain group of psychological dispositions transmitted in the womb of a given community by social contact and interdependencies from the entire system of interpersonal relations" [27, p.163]. It is “(...) communities, (...) indigenous peoples, groups and, in some cases, individual persons, according to the Unesco Convention, that play a significant role in the creation, protection, maintenance and reproduction of intangible cultural heritage (...) which are passed down from generation to generation, is constantly reproduced by communities and groups in relation to their surroundings, the impact of nature and their history, and provides them with a sense of identity and continuity (...)" [32]. Gathering memories from people still living in these communities is therefore the most important means of preserving their culture. However, it should not be understood only as a retrospective event or commemoration of local history, but above all, as activity directed towards the future [38, p.84, citing: 46].

This intergenerational transmission of information has an extremely important semantic core that can not be translatable over other content that can bring mutual benefit. On the one hand, it can play a leading role in maintaining a sense of identity and maintaining cultural continuity within the rural community. On the other hand, it can contribute to the consolidation, dissemination and connection of traditional (spiritual and material) culture - with universal culture, by respecting the past, present and future. This is probably the last moment to use and transfer the knowledge of the communities living here to the next generation, and a step towards preserving the traces of the past. Borderland homes, as places of value, will survive in as much as society will be able to reproduce them [39, p.432]. Heritage, as Gregory Ashworth wrote, "is a decision to draw from the past or [and] pass on to the future" [40, p.44].

\section{Acknowledgement}

The study has been implemented from the resources of the WZ/AiU/2/2020 public research funds financed by the Ministry of Science and Higher Education of Poland.

\section{References}

[1] Giddens A., Nowoczesność i tożsamość. Warszawa 2007. 1-322. 978-83-01-14691-7.

[2] Sadowski A., Społeczne problemy wschodniego pogranicza. Dział Wydawnictw Filii Uniwersytetu w Białymstoku, Białystok 2001.

[3] Sadowski A., Społeczne problemy miejscowości pn.-wsch. Polski w procesie transformacji. Białystok 2001. 83-89031-11-6.

[4] Barwiński M., Podlasie jako pogranicze narodowościowo-wyznaniowe. Łódź 2004. 83-7171-789-X.

[5] Sadowski A., Wschodnie pogranicze w perspektywie socjologicznej. Wyd. Ekonomia i Środowisko, Białystok 1995. 83-85792-15-X.

[6] Barwiński M., Podlasie jako region pogranicza, [in:] Studia z Geografii Politycznej i Historycznej, vol. 3 (2014), p. 281-306. Available: http://sgph.geo.uni.lodz.pl/uploads/files/t3/11-Barwinski.pdf [Access: 05.02.2020]

[7] Hawryluk J., Kraje ruskie, Bielsk, Mielnik, Drohiczyn. Rusini - Ukraincy na Podlaszu - fakty i kontrowersje. Podlaskie Wydawnictwo „Osnowy”, Bielsk Podlaski 2001. 83-914297-1-7.

[8] Sadowski A., Narody wielkie i małe. Uniwersytet Religioznawstwa, Uniwersytet Jagielloński, Kraków 1991.

[9] Sulima M., „Społeczno-kulturowy tygiel pogranicza etnicznego: tradycja i nowoczesność (na przykładzie wsi podlaskiej)", [in:] Habitaty: reaktywacja matych społeczności lokalnych/ Habitats: Reactivation of small local societies, edit. Z. Bać, Oficyna Wydawnicza Politechniki Wrocławskiej, Wrocław 2016. 506-514. 
[10] Pokropek M., Pokropek W., „Tradycyjne budownictwo drzewne w Polsce”, [in:] T.1: Budownictwo ludowe. Chatupy i ich regionalne zróżnicowanie. Neriton, Warszawa 1985.

[11] Szewczyk J., Piec i komin w tradycyjnym budownictwie ludowym Podlasia. Oficyna Wydawnicza Politechniki Białostockiej, Białystok 2011.

[12] Sielicki F., Folklor białoruski. Wrocław 1983.

[13] Sulima M., Dom pogranicza w kulturze wsi podlaskiej. Oficyna Wydawnicza Politechniki Białostockiej, Białystok 2018, s. 1-277. 978-83-65596-56-7.

[14] Pawluczuk W., „Prawosławie jako typ kultury. Prawosławie jako typ kultury”, [in:] Materiaty I edycji Wszechnicy Kultury Prawosławnej 1998/1999, edit. Zieniuk J., Białystok 1999, p. 41-48.

[15] Bułgakow S. Prawosławie. Zarys nauki kościoła prawosławnego. Orthdruk, Formica, Białystok, Warszawa 1992.

[16] Sulima M., „Gra symboli w detalu okna domu wiejskiego”, Czasopismo Techniczne, Architektura, R. 109, z. 15-t. 2 (2012), 2012, p. 576-581.

[17] Kozera A. N., Z badań nad folklorem muzycznym Podlasia. Portrety muzyków ludowych. http:// chopin.man.bialystok.pl/umfc/wp-content/uploads/2016/04/03-01.pdf [Access: 04.11.2019]

[18] Tołstaja S. N., Ojczyzna w ludowej tradycji słowiańskiej. Pojęcie ojczyzny we współczesnych językach europejskich. Instytut Europy Środkowo-wschodniej, Lublin 1993. 1-318. 83-85854-08-8.

[19] Eliade M., Sacrum i profanum. Wydawnictwo KR, Warszawa 1996. 83-86989-06-8.

[20] Kolberg O., Dzieła wszystkie. Białoruś - Polesie, t. 52, Polskie Towarzystwo Ludoznawcze Wrocław - Poznań 1968.

[21] Bachelard G., Wyobraźnia poetycka. Państwowy Instytut Wydawniczy, Warszawa 1975.

[22] Rembierz M., „Egzystencjalne i aksjologiczne doświadczenie domu rodzinnego”, [in:] Kultura dnia codziennego i światecznego w rodzinie, edit. Dyczewski L., Wadowski D., Redakcja Wydawnicza Katolickiego Uniwersytetu Lubelskiego, Lublin 1998, p. 41-58.

[23] Benedyktowicz D., Benedyktowicz Z., Symbolika domu w tradycji ludowej (part I). Polska Sztuka Ludowa (3), 1990, 48-61.

[24] Bartmiński J., Ojczyzna w pieśniach i wierszach chłopskich. Polska Sztuka Ludowa (3), 1990, 9-13.

[25] Ossowski S., O ojczyźnie i narodzie. Warszawa 1984. 83-01-04021-1.

[26] Buczyńska-Garewicz H., Miejsca, strony, okolice. Przyczynek do fenomenologii przestrzeni. Kraków 2006. 83-242-0608-6.

[27] Ossowski S., Z zagadnień psychologii społecznej. Dzieła, t. III. PWN, Warszawa, 1967.

[28] Bartmiński J., Polskie rozumienie ojczyzny i jego warianty. Pojęcie ojczyzny we wspótczesnych językach europejskich. edit. J. Bartmiński, Instytut Europy Środkowo-Wschodniej, Lublin 1993. 23-48. 83-85854-08-8.

[29] Hałas E., „Intymne wartości domu”, [in:] Kultura dnia codziennego i światecznego w rodzinie, edit. Dyczewski L., Wadowski D., Redakcja Wydawnicza Katolickiego Uniwersytetu Lubelskiego, Lublin 1998, p. 31-40. 83-228-0664-7.

[30] Wieruszewska M., „Krajobraz kulturowy wsi w percepcji wizualnej”, [in:] Lokalne dziedzictwo kulturowe w doświadczeniu mieszkańców wsi, edit. Bukraba-Rylska I., Wieruszewska M., Burdyka K., IRWIR PAN, Warszawa 2017, p. 1-242. 978-83-7383-876-5.

[31] Bernat S., „Niematerialne wartości krajobrazów kulturowych”, [in:] Niematerialne dziedzictwo kulturowe: źródła, wartości, ochrona, edit. Adamowski J., Wydawnictwo Uniwersytetu M. Curie-Skłodowskiej, Narodowy Instytut Dziedzictwa, Lublin-Warszawa, 2013, p. 1-367. 978-83-7784-426-7. 
[32] UNESCO Convention for the Safeguarding of the Intangible Cultural Heritage 2003. Available: http://www.unesco.pl/fileadmin/user_upload/pdf/Konwencja_o_ochronie_dz._niemater_2003.pdf [Access: 15.10.2019]

[33] National Heritage Board of Poland, UNESCO nonmaterial cultural heritage. Available: https:// www.nid.pl/pl/Dla_wlascicieli_i_zarzadcow/opieka-nad-zabytkami/niematerialne-dziedzictwo-kulturowe-unesco/ [Access: $15.10 . \overline{2} 018]$

[34] Sulima M., Dom mieszkalny w zagrodzie pogranicza etnicznego jako zjawisko architektoniczno-kulturowe (na przyktadzie wsi podlaskiej). PhD desideration. Faculty of Architecture, Warsaw University of Technology, Warszawa 2013.

[35] Janowicz S., Ojczystość. Białoruskie ślady i znaki. WK Borussia Olsztyn 2001. 1-256. 83-915690-0-4.

[36] Durydiwka M, Kociszewski P, „Wielokulturowość Podlasia i możliwości jej wykorzystania w turystyce". Available: http://www.turystykakulturowa.org/pdf/2013_06_01.pdf [Access: 05.01.2020]

[37] UNESCO Convention Concerning the Protection of the World Cultural and Natural Heritage. Available: http://www.unesco.pl/fileadmin/user_upload/pdf/Konwencja_o_ochronie_swiatowego_ dziedzictwa.pdf [Access: 15 Oct 2019]

[38] Waszczyńska K., „Przekaz międzypokoleniowy i jego znaczenie w kontekście konwencji UNESCO w sprawie niematerialnego dziedzictwa kulturowego. Refleksje etnologa”, [in:] Niematerialne dziedzictwo kulturowe: identyfikacja, dokumentacja, ochrona, interpretacja. Pojęcia, poglady, Materiały z Ogólnopolskiej Konferencji Naukowej Węgorzewo 2011, Warszawa - Węgorzewo 2013.

[39] Halbwachs M., Społeczne ramy pamięci. Wydawnictwo Naukowe PWN, Warszawa 2008. 1-438. 978-83-01-15511-7.

[40] Ashworth G., Planowanie dziedzictwa. Międzynarodowe Centrum Kultury, Kraków 2015. 1-314. 978-83-63463-34-2.

[41] Pawluczuk W., Światopogląd jednostki w warunkach rozpadu społeczności tradycyjnej. Warszawa 1972.

[42] Łokotko A., Belorusskoe narodnoe zodčestvo: seredina XIX-XX w.. Navuka i Technika, Mińsk 1991.

[43] Becker. H., Rozwój myśli społecznej od wiedzy ludowej do socjologii. Warszawa 1964.

[44] Tatarkiewicz T., W., Wspomnienia. Państwowy Instytut Wydawniczy, Warszawa 1979.

[45] Znaniecki F., Social Relations and Social Roles. San Francisco 1965.

[46] Hałas E., „Przeszłość i przyszła teraźniejszość: refleksyjna pamięć kulturowa”, [in:] Kultura jako pamięć. Posttradycyjne znaczenie przeszłości, 10 Jul 2011, Warsaw. 
